\title{
Production of Gluten-free Bread Based on Rational Use of Natural Resources
}

\section{A V Khmelevskaya, A A Burnatseva, M || Gusalova, and | T Karaeva}

K.L. Khetagurov North Ossetian State University, Vladikavkaz, Russia

\section{Abstract}

The paper provides scientific foundation for an integrated approach to the problem of expanding the range of bread for special purposes, including that for patients with celiac disease. High cost of gluten-free foreign products makes rational use of corn flour and bread production technology based on it currently relevant. The use of enzymatic modification of corn flour starch is found to increase the gas formation of dough, which increases accumulation of mono- and disaccharides up to $5.5 \%$. The use of surfactants to increase the gas retention capacity of dough is proved to be expedient. The effect of deoiled soy lecithin on the properties of dough and qualitative characteristics of corn bread was discovered. Dry egg albumen was added to make the bread structure porous. Preliminary hydration of protein was revealed to improve

Corresponding Author:

A $\vee$ Khmelevskaya

macintosh.alina@yandex.ru

Received: 25 October 2019

Accepted: 15 November 2019

Published: 25 November 2019

Publishing services provided by Knowledge E

(c) A V Khmelevskaya et al. This article is distributed under the terms of the

Attribution License, which permits unrestricted use and redistribution provided that the original author and source are credited.

Selection and Peer-review under the responsibility of the AgroSMART 2019 Conference Committee. leavening of bread. It was proved that semi-finished product, hydrolysate, in an amount of $50 \%$ of the corn flour weight, $1 \%$ soybean deoiled lecithin, $2.5 \%$ vegetable oil, and $4 \%$ dried egg albumen increase the gas retention capacity of dough and reduce its viscosity and gelatinization temperature to produce high quality gluten free corn pan bread.

\section{Introduction}

In bakery, it is currently important to expand and improve the range of therapeutic and prophylactic products. The consumer needs cheap quality products, including those produced using non-traditional types of raw materials. Achloride iodine containing products were developed for people suffering from osteoporosis and diabetes mellitus [1].

Celiac disease or gluten enteropathy is an increasingly spreading disease. In Europe, America and India, up to $1--1.2 \%$ of the population suffers from gluten intolerance, which causes damage to intestinal villi of the mucous membrane. These people have to keep a lifelong diet. Products made from rice, corn, buckwheat, and millet are most often used as a substitute for gluten-containing products from wheat, oats, barley and rye [2--5]. Today, gluten-free products are produced mainly by EU countries: Germany, Italy and Finland. However, it should be noted that these products are of high cost [6]. 
In general, modern technologies only partially replace wheat flour with gluten-free types of flour made from cereals and legumes in production of bakery and flour products [7]. This is primarily due to the lack of gluten-forming proteins in these types of flour, which are known to affect structural and mechanical characteristics of semi-finished and finished products. Therefore, the technology for gluten-free bakery products of low cost for treatment-and-prophylactic nutrition based on non-traditional raw materials is becoming crucial.

The analysis showed that the most promising type of this raw material is maize gluten meal made from anti-allergenic food corn [8, 9]. However, baking properties of this flour are low, it does not form the dough with required structural and mechanical characteristics, and the products are small in size and crumbly.

Data on the use of hydrocolloids as additives, which positively affect structural and mechanical properties of semi-finished and finished products, are reported in [10].

It should also be considered that to obtain the appropriate structural and mechanical characteristics of the finished bakery products, a sufficient number of simple sugars, the food source for the yeast during alcoholic fermentation, are required. The content of intrinsic sugars in corn flour is low (up to $1.15 \%$ ), and the activity of intrinsic amylolytic enzymes in flour is also low. Therefore, to obtain a sufficient amount of carbon dioxide to leaven the dough, simple sugars should be added or produced by starch modification. Corn flour is a promising type of raw material for these purposes, since its starch content is $65--70 \%$. In bakery, fungal $\alpha$-amylase preparations are used for starch hydrolysis, and the hydrolysis proceeds with the formation of maltodextrins and maltose. For more complete saccharification, glucoamylase preparations are used [11]. A complex use of these enzyme preparations will not only ensure the presence of fermentable sugars in dough, but also increase the shelf life of bakery products. Therefore, enzyme preparations with amylolytic activity should be used to prepare gluten-free bakery products from corn flour. Analysis of the literature indicates the need to use additives with structure-forming properties (gums, lecithins, etc.) in baking gluten-free flour products to ensure the gas retention capacity of semi-finished products and to increase the dough stability. As is known, lecithins exhibit high water-retaining and emulsifying ability and are a valuable source of phospholipids. For baking, it is recommended to use these surfactants with a hydrophilic-lipophilic balance of $6--14$, and the recommended dosage is $1--4 \%$ of the flour weight [12].

The formation of the required structural and mechanical characteristics of bakery and flour products can be facilitated by the egg albumen, which possesses high foaming ability. Possessing hydrophilic-hydrophobic properties of frothers make them concentrate 
on the interface thus reducing surface tension. Egg products affect the porosity formation and enrich products with high-grade protein. Consequently, amylolytic enzyme preparations, lecithin and egg white can affect microbiological processes, the formation of structural and mechanical characteristics of products, which indicates the need for further research.

The study aims to determine the possibility of using fungal $\alpha$-amylase and glucoamylase, deoiled soy lecithin and egg albumen to make gluten-free bread from the corn flour.

In accordance with the aim, it is required:

- to determine the parameters of starch modification;

- to investigate the effect of deoiled soy lecithin and egg protein (dry) on structural and mechanical characteristics of semi-finished and finished products; to determine their dosage;

- to study structural and mechanical characteristics of the corn gluten-free dough prepared using enzyme-modified corn flour, deoiled soy lecithin and dried egg albumen, and the quality of the finished products.

\section{Materials and Methods}

To conduct the study, a sample prepared according to the recipe for bread made by the straight dough procedure was used as the control: $100 \mathrm{~kg}$ of corn flour; $3 \mathrm{~kg}$ of pressed baking yeast; $1.3 \mathrm{~kg}$ of salt. The dough with a moisture content of $54 \%$ without fermentation was divided into portions shaped and placed in molds. At a temperature of $38 \pm 2{ }^{\circ} \mathrm{C}$, the dough was proved until ready. Baking was carried out at $200--220^{\circ} \mathrm{C}$.

Cornmeal was hydrolyzed using fungal $\alpha$-amylase preparations (activity of 5000 unit/g) and igluco-amylase (activity of 500 unit/g). The temperature optimum of enzyme preparations and that of dough preparation was different; therefore, the first prepared semi-finished product was hydrolysate made from part of corn flour and water at 40 ${ }^{\circ} \mathrm{C}$. The mass was acidified with citric acid $(0.065 \%$ of the flour weight) to ensure the optimum pH value, and enzyme preparations diluted with water in the ratio of 1:10 were introduced. The mass was placed in a thermostat at $40^{\circ} \mathrm{C}$ until sugar accumulated in it in an amount up to $6 \%$. The semi-finished hydrolyzate was used to prepare the dough with a moisture content of $54 \%$ of the remaining amount of corn flour, yeast suspension, and salt solution in accordance with the recipe. Bread samples were prepared through the straight dough procedure using the hydrolyzate. In addition to the above-mentioned 
additives, soybean powder of deoiled lecithin was used to make subsequent bread samples, which was introduced into to the mass after its enzymatic treatment adding 2.5 $\%$ vegetable oil. The mass was dispersed for 2--3 minutes to knead dough. The fourth sample of corn bread was prepared using dry pasteurized egg albumen preliminary diluted in water at $30{ }^{\circ} \mathrm{C}$ in a ratio of $1: 7$ and whipped for 5 minutes to obtain a stable foam.

The amount of sugars formed during starch hydrolysis was measured by the iodometric method. The intensity of alcoholic fermentation was estimated by the method of lago-Ostrovsky. Acidity of semi-finished products was determined by standard methods [13]. The visco-plastic properties of dough were evaluated by changing the diameter of the 100 gram dough ball during its fermentation at $30^{\circ} \mathrm{C}$.

The gas retention capacity of dough was monitored through changes in the specific volume of test samples in a $250 \mathrm{~cm}^{3}$ cylinder in a thermostat at a temperature of $30^{\circ} \mathrm{C}$ until dough dropped.

The finished samples were analyzed 4 hours after baking using organoleptic and physicochemical parameters according to conventional methods [13].

\section{Study of the effect of amylase, lecithin and protein on the ability of gluten-free corn bakery products}

The rate of starch cleavage by amylases depends on its structural features, and on the size and shape of starch grains. Therefore, dosage recommendations for enzyme preparations proposed by manufacturers may not be appropriate for the hydrolysis of corn flour starch. The optimal dosage of enzymes was calculated through determination of mono- and disaccharides in the model test system with corn flour of $54 \%$ humidity and water at $40{ }^{\circ} \mathrm{C}$ after 3 hours of yeasting.

As can be seen in Figure 1, the addition of fungal $\alpha$-amylase at a dosage of 0.005$-0.007 \%$ of the weight of corn flour leads to $3.0--4.2 \%$ accumulation of sugars which is $43--42 \%$ more than that when adding this enzyme at a dosage of $0.002 \%$. The enzyme dosage increased up to more than $0.005 \%$ does not significantly increases sugars as compared to that at a dosage increased from 0.002 to $0.005 \%$. An increase in the dosage of glucoamylase from 0.04 to $0.05 \%$ is impractical, since more significant accumulation of sugars ( $5 \%$ ) during hydrolysis occurs when making the enzyme preparation at a dosage of $0.03 \%$ of the weight of corn flour. As reported earlier, alcoholic fermentation and baking require up to $6 \%$ of simple sugars on a dry basis. 


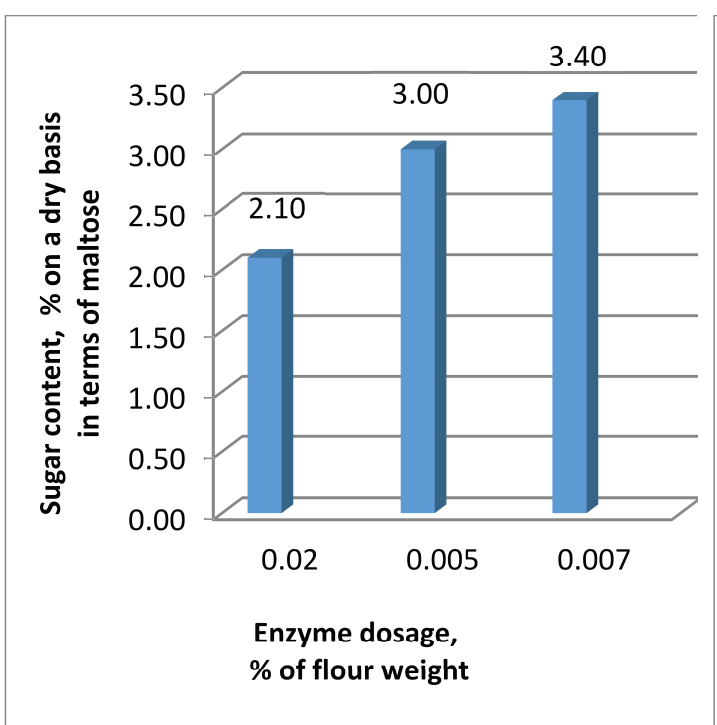

(a)

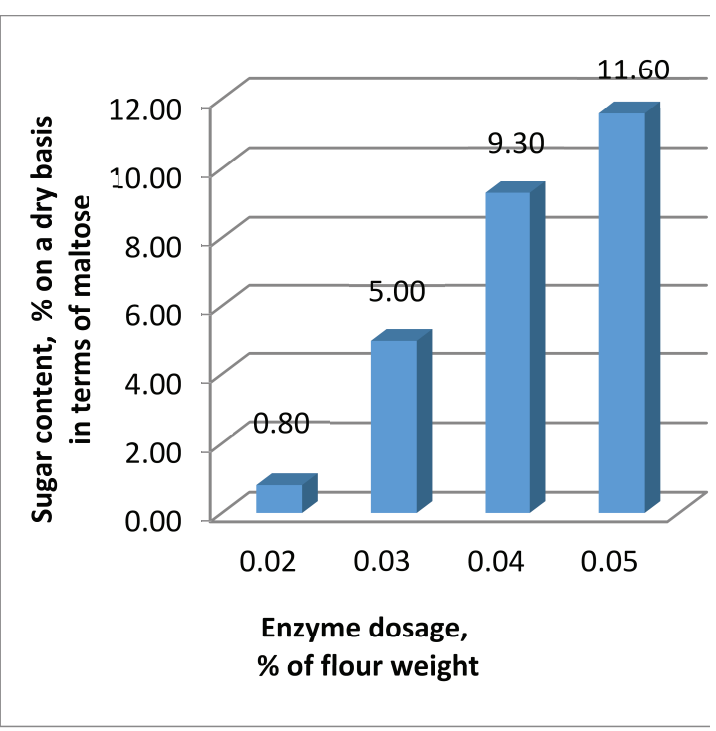

(b)

Figure 1: Effect of enzymes on accumulation of sugars in corn dough: (a) fungal $\alpha$-amylase; (b) glucoamylase.

Therefore, the dosage of fungal $\alpha$-amylase required for the corn starch modification is $0.005 \%$, and the amount of glucoamylase required is $0.03 \%$ of the weight of corn flour. The obtained semi-finished product -- hydrolyzate -- was used for dough preparation.

In addition to the medium temperature and acidity, the moisture content of the substrate affects the amylolytic enzymes. Figure 2 presents the dynamics of the accumulation of sugars during the hydrolysis of corn flour with its different contents in the initial mixture.

The use of corn flour in an amount of $50 \%$ of the recommended one in the hydrolyzate with a moisture content of $65 \%$ (Figure 2, Curve 3) contributed to a greater accumulation of sugars, which is associated with the enzyme-substrate ratio. The amount of sugars (up to $6 \%$ ) sufficient for yeasting and baking is formed within 2 hours of hydrolysis with optimal parameters.

In further studies, we investigated the effect of deoiled soy lecithin on physicochemical parameters of the corn dough (Table 1) due to the absence of gluten-forming proteins, which are mainly responsible for rheological properties. The lecithin dosage in corn flour was $0.5-1.5 \%$ of the weight of corn flour.

It can be noted that the use of deoiled soy lecithin had a positive effect on characteristics of dough and the ability of the bread made from corn flour. Thus, during 45 minutes of yeasting the gas-forming capacity increased by 25.0--27.9 \% compared to that in the control sample. The specific volume of bread increased by 9.8, 17.6, 19.6 $\%$, respectively when adding $0.5,1.0,1.5 \%$ lecithin. The bread porosity increased by 


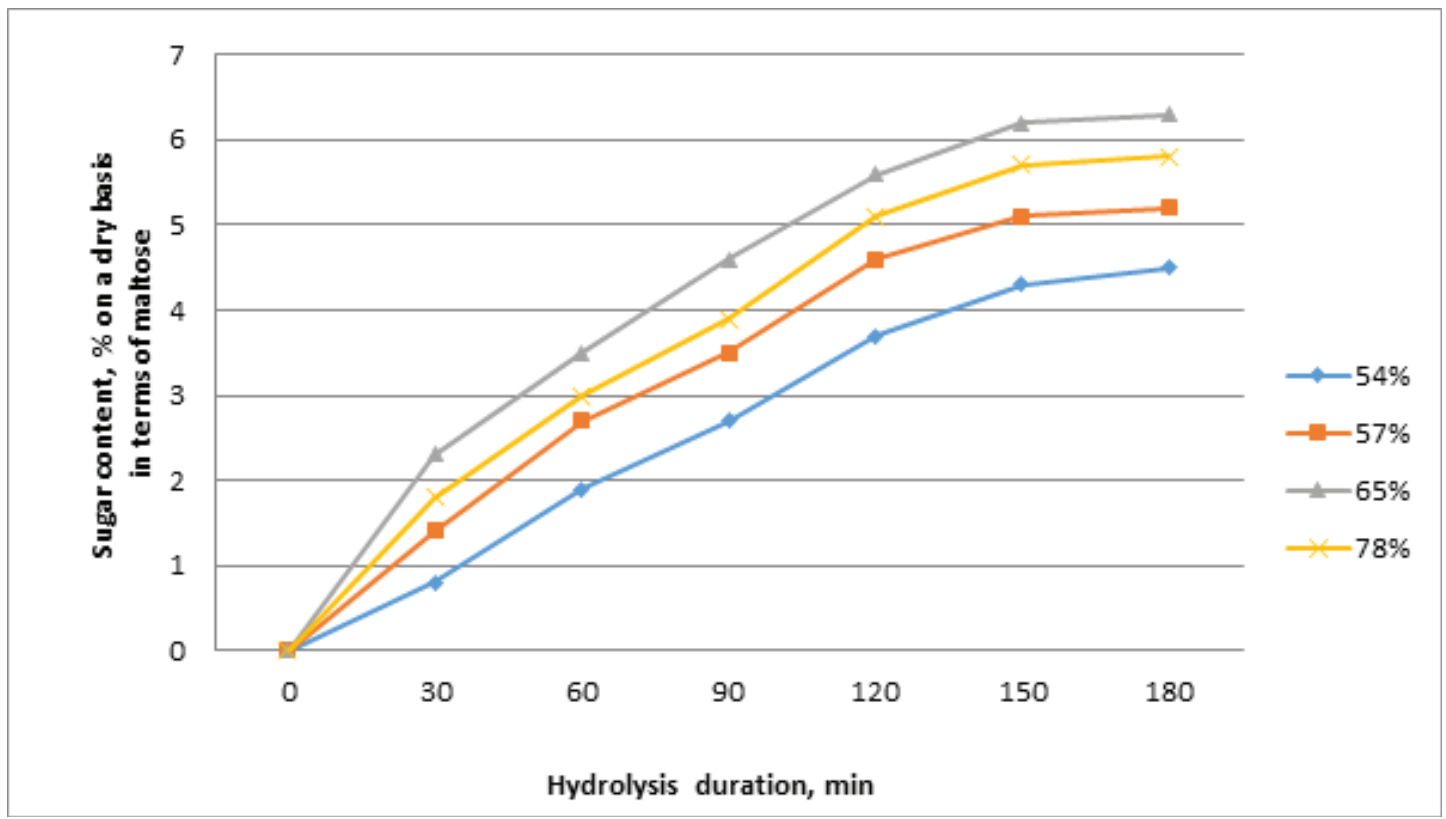

Figure 2: Accumulation of sugars in the semi-finished product (hydrolysate) depending on its moisture content with the content of corn flour: (1) $100 \%$; (2) $75 \%$; (3) $50 \%$; (4) $25 \%$.

TABLE 1: Effect of deoiled soy lecithin on the test indicators and the ability of corn bread.

\begin{tabular}{|c|c|c|c|c|}
\hline \multirow[t]{2}{*}{ Indicator } & \multirow[t]{2}{*}{$\begin{array}{c}\text { Control (with } \\
\text { amylase enzymes) }\end{array}$} & \multicolumn{3}{|c|}{$\begin{array}{l}\text { Sample with amylases and lecithin, \% of the weight of } \\
\text { corn flour }\end{array}$} \\
\hline & & 0.5 & 1.0 & 1.5 \\
\hline \multicolumn{5}{|c|}{ Dough } \\
\hline $\begin{array}{l}\text { Gas-forming capacity } \\
\text { ( } 45 \text { min before } \\
\text { yeasting), } \mathrm{cm}^{3} / 100 \mathrm{~g} \text { of } \\
\text { dough }\end{array}$ & 340 & 425 & 435 & 435 \\
\hline \multicolumn{5}{|l|}{ Titrated acidity, deg: } \\
\hline - initial & 2.7 & 2.7 & 2.7 & 2.8 \\
\hline - final & 3.3 & 3.4 & 3.5 & 3.5 \\
\hline $\begin{array}{l}\text { Specific volume }(45 \mathrm{~min} \\
\text { after yeasting), } \mathrm{cm}^{3} / \mathrm{g}\end{array}$ & 1.35 & 1.45 & 1.56 & 1.58 \\
\hline \multicolumn{5}{|c|}{ Bread } \\
\hline Specific volume, $\mathrm{cm}^{3} / \mathrm{g}$ & 1.53 & 1.68 & 1.80 & 1.83 \\
\hline Acidity, deg & 2.8 & 2.9 & 3.0 & 3.0 \\
\hline Porosity, \% & 40.8 & 43.7 & 46.9 & 47.3 \\
\hline
\end{tabular}

$7.1 \% ; 15.0 \% ; 15.9 \%$. The introduction of lecithin at a dosage of $1.0 \%$ of the weight of corn flour contributes to a greater increase in both the specific volume of bread and its porosity index. Vegetable oil at a dosage of $2.5 \%$ affects the surface-active properties of lecithin and contributes to a greater increase in the specific volume of bread and its porosity. 
To ensure the structure of porosity and the specific volume of the corn bakery product, dried egg albumen was introduced in an amount of 3.08, 4.08, 5.08 \% of the flour weight after its pre-dilution with water and whisking until a persistent foam (Table 2).

TABLE 2: Effect of dried egg albumen on the ability indicators of corn dough and bread.

Indicator
Gas-forming capacity
(45 min before
yeasting), $\mathrm{cm}^{3} / 100 \mathrm{~g}$ of
dough
Titrated acidity, deg:
- initial
- final
Specific volume $(45 \mathrm{~min}$
after yeasting), $\mathrm{cm}^{3} / \mathrm{g}$

Analysis of data presented in Table 2 indicates that the addition of dried egg albumen increases slightly the acidity of dough, while the addition of 3.0 to $5.0 \%$ of protein decreases the gas-forming capacity by $0.5-1.2 \%$, which is likely due to the decreased nutrient supply to yeast cells. When adding the specified amount of protein, the specific volume of dough and bread increases by $23.8--26.2 \%$ and by $24.0--26.1 \%$, respectively. At the same time, the introduction of this additive in an amount of more than $4.0 \%$ decreases the specific volume; therefore, the dosage of 3--4 \% should be considered optimal.

The samples with protein exhibited better organoleptic characteristics compared to the control sample, due to a more intensive reaction of melanoidin formation. To explain the increased specific volume of the samples, we investigated changes in the viscoplastic characteristics of corn dough (Figure 3).

As can be seen, dough slackness in samples with additives is higher by 20.0--30.0 $\%$. The introduction of additives and the processes occurring during yeasting contribute to the decreased dough viscosity. At the same time, additives cause an increase in the gas retention capacity of dough and the volume of bread (Tables 1 and 2), since 


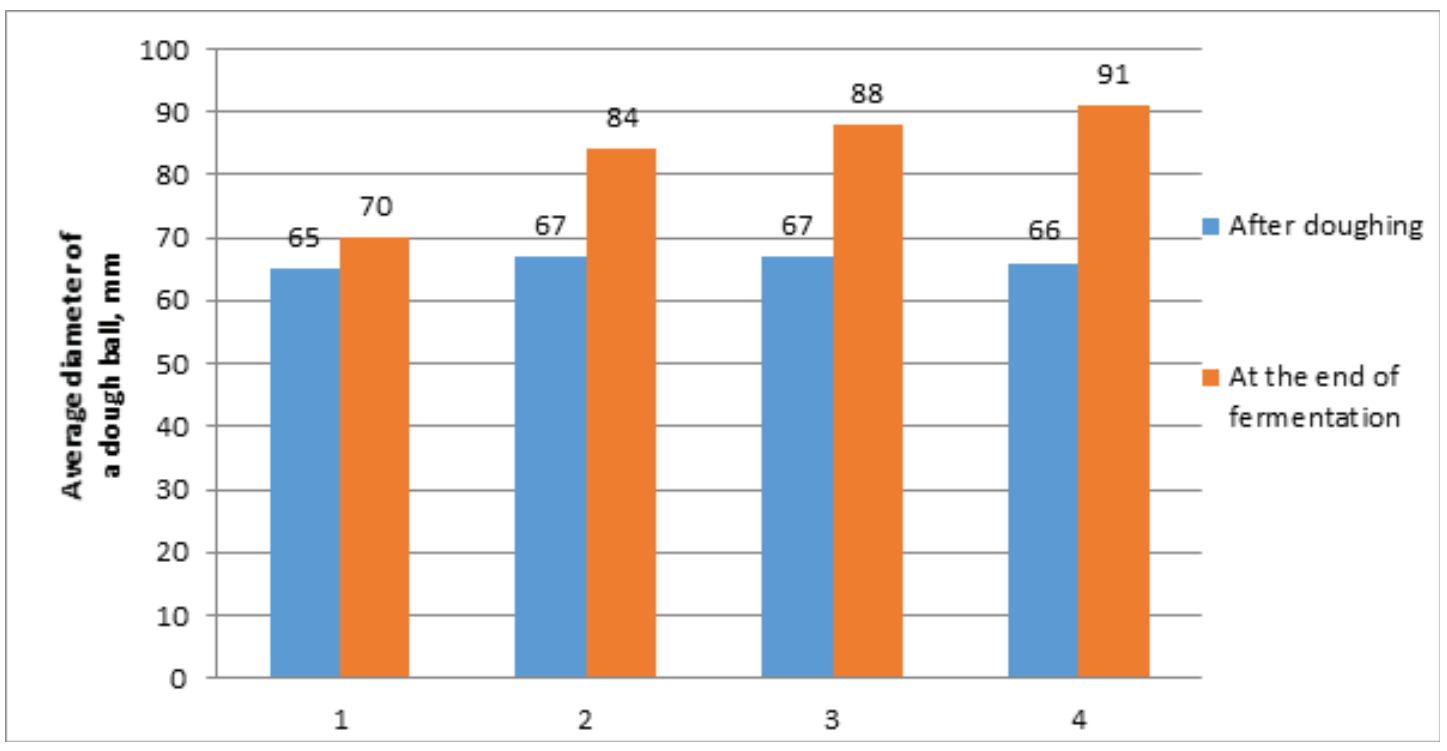

Figure 3: Dough slackness: 1 -- control (without additives); 2 -- with amylase enzymes; 3 -- with enzymes and lecithin; 4 -- with enzymes, lecithin, and egg albumen.

lecithin reduced the surface tension and interfered with coalescentin. An egg albumen significantly affected the formation of the structure, which strengthened the structure during denaturation and retained carbon dioxide. Due to a greater decrease in the dough viscosity caused by additives, gas bubbles expanded more, which contributed to a greater increase in the volume of finished products. In addition, the temperature of gelatinization was observed to decrease from 64 to $59^{\circ} \mathrm{C}$; therefore, the decreased retrogradation of corn starch caused by additives will slow firming of bread.

\section{Conclusions}

The study showed that the addition of amylolytic enzymes at a dosage of $0.005 \%$ and glucoamylase at a dosage of $0.03 \%$, deoiled soy lecithin at a dosage of $1.0 \%$, vegetable oil at a dosage of $2.5 \%$, and dried egg albumen at a dosage of $4 \%$ increased the gas retention capacity of dough that results in the aerated structure of gluten-free bread which less likely to go stale quickly as compared to the control.

\section{References}

[1] Barsukova, N.V., Reshetnikov, D.A., Krasilnikov, V.N. (2011). Food engineering: glutenfree floury products technology. Nauchnyy Zhurnal NIU ITMO, vol. 1, pp. 1--11.

[2] Palma, G., Nadal, I., Collado, M.C., Sauz, Y. (2009). Effects of a gluten-free diet on gut microbiota and immune function in healthy adult human subjects. British Journal 
of Nutrition, vol. 102, pp. 1154--1160.

[3] Renzetti, S., Dal Bello, F., Arendt, E.K. (2008). Microstructure, fundamental rheology and baking characteristics of batters and breads from different gluten-free flours treated with a microbial transglutaminase. Journal of Cereal Science, vol. 48, no. 1, pp. 33--45.

[4] Numes, M.H., Moone, M.M., Ryanh, A.M., Arendt, E.K. (2008). Impact of emulsifiers on the ability and rheological properties of gluten-free breads and batters. European Food Research and Technology, vol. 228, no. 4, pp. 633--642.

[5] Burnatseva, A.A., Khmelevskaya, A.V. (2018). Promising directions of integrated use of corn processing products for the production of specialized food products. Actual problems of biology and ecology. Makhachkala: ALEF, pp 131--136.

[6] Biagi, F., Andreall, A., Bianchi, P.M., Marchese, A., Klensy, C., Corazza, G.R. A glutenfree diet score to evaluate dietary compliance in pateents with celiac disease. British Journal of Nutrition, vol. 102, pp. 882--887.

[7] Gomez, M., Ruiz-Paris, E., Oliete, B. (2010). Influence of flour mill streams on cake ability International. Journal of Food Science and Technology, vol. 45, pp. 1794-1800.

[8] Renzyaeva, T.V., Tuboltseva, A.S., Artuschina, S.I. (2015). Development of recipes and technologies for gluten-free cookies based on natural plant materials. Food Processing: Techniques and Technology, vol. 39, no. 4, pp. 87--91.

[9] Drobot, B., Mykhonik, L., Gryschenko, A. (2017). Influence of structure forming food additives on the ability of gluten-free bread made from the mixture of rice and corn flour. Scientific works of NUFT, vol. 23, no. 6, pp. 169--175.

[10] Mysakov, D.S., Grashchenkov, D.V., Chugunova, J.V. (2016). Prospects for the use of xanthan Gum. Polysaccharide of Microbial Origin in gluten-free goods production. Bulletein of the South Ural State University Ser. Food and Biotechnonlogy, vol. 4, no. 4, pp. 26--35.

[11] Rimarova, L.V., Serba, E.M., Sokolova, E.N. (2017). Enzyme preparations and biocatalytic processes in the food industry. Voprosy pitania, vol. 86, no. 5, pp. 63--74.

[12] Kornen, N.N., Pershakova, T.V., Lisovaya, E.V. (2016). Application of lecithin in bakery products manufacture. Retrieved from: http://ej.Rubago.ru/2016/02/pdf/21.pdf.

[13] Koryachkina, S.Y. et al. (2012). Ability control of raw materials, semi-finished products and bakery products. Moscow: Delhi Plus, $495 \mathrm{p}$. 